\title{
GEOMETRICAL FORMS, MODEL AND SPACE CONCEPT IN INTERIOR ARCHITECTURE EDUCATION
}

\author{
Assist. Prof. Arzu ECEOGLU \\ Istanbul Kultur University, Faculty of Arts and Design, Turkey \\ arzueceoglu@gmail.com
}

\begin{abstract}
As an example for "Interior Architecture" educations given in various faculties of universities, this work is on creating space designs via models, which are made to establish the understanding of students on scale, rate and ratio. The syllabus of Interior Architecture departments aims to develop the students' understanding on space and have them get better results in terms of perception. What really matters is for student to understand the space concept and get the knowledge required for reaching the right conclusions on space organization. In the later stages, created by the usage of different materials with the aim of developing space design integrity, student projects are supported to make a difference in collaboration with arts and science. The aim of this work is to analyze and show the development of design concept through the models prepared within the extent of space organization courses, the roles of geometrical forms during the design phase and the setup of the models created, by using Le Courbisie's first house model named cell.
\end{abstract}

Keywords: Interior Architecture, Space Organization, Le Courbisie, Design phase, Model

\section{İÇ MIMARLIK EĞITTIMINDE GEOMETRIK FORMLAR, MAKET VE MEKAN OLGUSU}

$\ddot{O Z Z}$

Bu çalışma, üniversitelerde farklı fakültelerde okutulan "İç Mimarlık" eğitimlerine örnek olması bakımından, ölçek, oran ve orantı kavramının daha iyi pekiştirilmesi için hazırlanan maket yardımı ile mekan tasarımlarının oluşturulması hakkındadır. İç Mimarlık bölümlerinde eğitim boyunca oluşturulan müfredatların amacı öğrencinin mekan olgusunu geliştirmek ve algısal açıdan daha iyi sonuçlar alınmasını sağlamaktır. Asıl olan öğrencinin öncelikle mekan olgusunu anlaması ve mekan organizasyonu ile ilgili doğru sonuca ulaşabileceği bilgiye ulaşmasıdır. İlerleyen safhalarda mekan tasarımı bütünlügünün geliştirilmesi amacıyla farklı materyallerin bir arada kullanılması düşüncesi ile oluşturulan öğrenci projelerinin sanat ve bilim ile birlikte farklılıklar yaratması sağlanmaktadır. Bu çalışmanın amacı Le Courbisie'nin, hücre olarak adlandırdığ $\breve{g}_{1}$ ilk ev modelinden yola çıkılarak, mekan organizasyonu ders kapsamında hazırlanan maketler yardımı ile tasarım kavramının geliştirilmesi, geometrik formların tasarım aşamasındaki yerini ve çalışma sonucunda ortaya çıkan maketlerin kurgularını irdeleyerek ortaya koymaktır.

Anahtar Kelimeler: İç Mimarlık, Mekan Organizasyonu, Le Courbisie, Tasarım aşaması, Model

\section{INTRODUCTION}

According to Le Corbusier, architecture is "the learned game, correct and magnificent, of forms assembled in the light." Formed by mass, spaces gain their characteristics through functionality, utility and attractiveness added by the geometrical forms. The geometrical forms, which creates the mass, helps individual (student) develop a perception on space, comprehension, and visual and intellectual abilities, which he/she will need in his/her profession; because, all construction 
and fitting elements, all accessories are products of geometrical forms and arise from inspiration on the modeling of these forms. The most significant feature of the items and materials people use in their daily lives and the spaces they live in is the qualities of their formal structure[1]. For this reason, as of $1^{\text {st }}$ semester, courses, such as Basics of Design, Architectural Expression Techniques, Project, Interior Architectural Design, Space Organization, are given in universities to develop the formal perception of students during their architecture and interior architecture educations.

\section{SPATIAL PERCEPTION}

While it's very easy for individuals, who has had the required education for the profession and has improved themselves, to identify and analyze space concept and use it in their own applications, for individuals who has just began to have their vocational education, it's very hard to comprehend the spaces, which they are already a part of. Within the space organization education, the most important thing is to have students comprehend the space concept right.

- In forming a space, it doesn't have to be bordered by absolute barricades all around it.

- The most important difference that separates the space from the volume appears on this point. While the borders of a space can be physical that restraints the movement, it can also be something else that can be perceived with other senses, for example a visual appearance like a change in the floor pattern. The important thing is; the borders of the space, whether they're conspicuous or not, should be perceivable. Even though, while the space perception is discussed, eyesight, as a sensation, is given weight primarily and other sensation forms are ignored, perception is influenced by all senses in different proportions. It should be taken into consideration that perception consists of the composition of various senses and thus space perception is also under the influence of all.

While space is defined in different ways by various approaches, from a wider perspective, it can be defined as "a void that separates people from environment to some extent and suitable for them to continue their actions" and "a part of Space, the borders of which can be perceived by observer(s)". However Space is not an architectural space; but it's a "MEDIUM COMMUNICATIONAL SPACE". Sun, in the daytime, moon and stars in the nighttime, brings an important organization beyond the crust of earth.

Spatial perception is interpreted in different ways by different disciplines. While psychologists principally dwell on personal factors (sex, age, familiarity, etc.) that affect the spatial perception, urban planners and geographers principally dwell on environmental factors (form, pattern, etc.). Understanding what these factors are and how they affect the space perception, correctly, is important in designing livable areas that meet the needs of users and increase their satisfaction.

In creating architectural space, architect alters the physical space and creates a zone, using space indicative elements. In other words, architectural space is enclosed. Space is generally approached as a void between masses. However, substantially, space is a form between masses that have architectural forms by themselves. The difference between inside and outside forms is the essence of architecture [2]. For the observer, being inside is more favorable than being outside. Limiting elements constructed inside the space should set people's minds at rest. Through the borders and the accent elements that affect all senses in different rates, an observer perceives the space he/she is inside as a whole. From cells to high rise buildings, rectangular parallelepiped is the most common form used in spaces. Its natural static, ease of use and functional conditions have had this form to be used in all eras. [3]. The existence of geometrical forms in the creation of space has always been apparent. 
This is one of the most important and prominent points in vocational education process; because setting up the space organization schematic in the right way and forming space perception personally to meet the needs correctly is important for the progress of the individual.

\section{LE CORBUSIER AND THE SPACE CONCEPT}

Charles-Edouard Jeanneret, better known as Le Corbusier, was one of the pioneers of "Modern architecture, who changed the definition of architecture through his works and thoughts, and a versatile artist, who has works on various branches of arts including painting, sculpture and urban planning. He was influenced by T. Garnier's utopian socialist tendency and ideas on architecture, with whom he has met in 1907. Also the pension house in Galluzo, Toscana, where he stayed within the same year, has been very important for his career. He thought that this house was very suitable for commune life, which was the sociophysical model of the utopian socialist ideas of L'Eplattenier and Garnier, according to him. Especially, he was inspired by this model in his collective housing works. In 1910, he went to Germany to improve his knowledge on reinforced concrete and developed a relationship with the members of Wrkbund.

After working with Behrens in Berlin for six months, he went on a tour to East, which took four years intermittently and was the most important period of his education on architecture, according to him. The Ancient Greek architecture, Ottoman architecture and the local architectures of Balkans and Anatolia has been an important source of inspiration for him.

In 1915, he worked on Domino House, which was a new interpretation of "Hennebique" system and Pilotis Villas, which were lifted off the ground on stilts (pilotis); and these formed the structural base of the houses, he and his childhood friend, Swiss engineer Max du Bois, designed until 1935. In 1916, he used palace-house theme in his designs like Schwob and Turquie Villas, which remind of Palladio's villas with their symmetrical grate-like plans consist of consecutive narrow and wide sections. To form a ratio control on the façades, he used regulation lines compliant with golden ratio and he developed this palace-house theme in two separate sociocultural expressions in his future works. One of them is a stand-alone villa in Palladio style and the other one is collective housing works that makes an ideological reference to Falanster with its baroque place like plan.

According to Le Corbusier, "anything was beautiful, if it met the needs" and there were only two ways to attain beauty:

1- Proportional Geometry

2- Mutual relation between Form and Function

Le Corbusier, who has filled his 78 years of life with many qualities, has presented the importance of correct geometrical form choice and the harmony and connection between equipments through his first house model calles "Living Cell", which was exhibited at an International Decorative Arts Exhibition in Paris in $1925^{1}$.

\footnotetext{
1 In 1922, he started working with his nephew Pierre Jeanneret'yle (1896-1967), a collaboration lasts until World War II, and within the same year, they developed batch production Domino Houses and Pilottis Villa projects within the extent of Citroban House and Modern City works. As a simple cubic form, Citroban House was important as it presented Le Corbusier's "Five Points of Architecture": lifting the structure off the ground on stilts, roof garden, plan elasticity via the usage of reinforced concrete carcass system, long strips of ribbon windows and free façade. Le Corbusier designed Mayer Villa, Esprit Nouveau Pavilion in Paris Decorative Arts Exhibition in 1925, Stein / De Monize Villa in 1927 and Savoye Villa in 1929, in the same sense.
} 


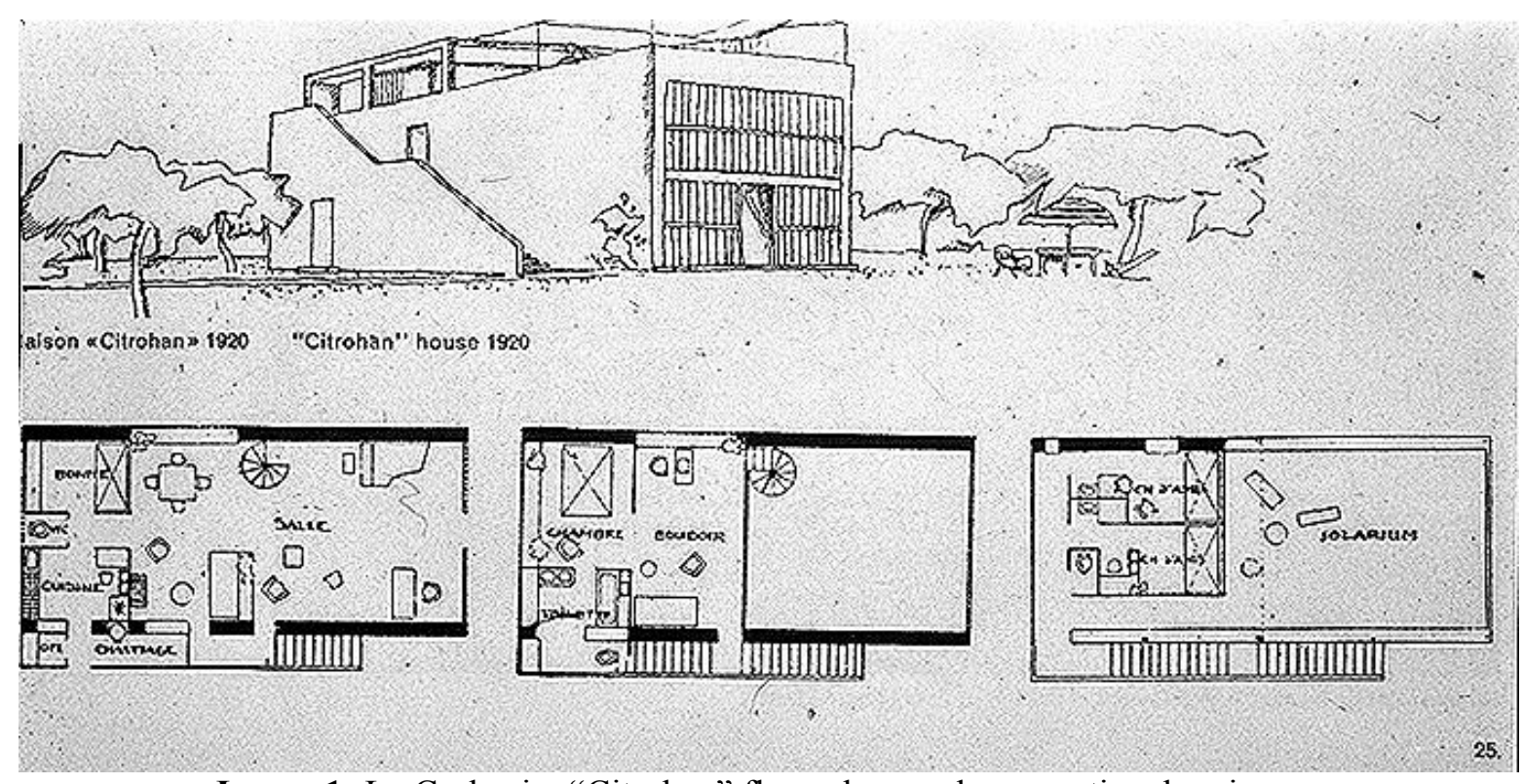

Image 1: Le Corbusier "Citroban" floor plans and perspective drawing

For the designer, "Free Plan" motto has a great significance. But the meaning of the word "free" in this concept is the perfect connection between the essential characteristics of the objects and their setup. In this sense, he based his understanding of architecture on five basic principles:

1- Non-supporting walls by using columns for carrying all the bulk,

2- Supporting elements of the structure and the walls having functions independent from each other,

3- Usage of reinforced concrete structure, not only as a technical element, but as an aesthetical element,

4- Illumination of the interior space via long strips of ribbon windows, as a part of free façade,

5- Transformation of roofs into roof gardens.

Le Corbusier uses all these ideas in "Villa Savoya", which rises up to the sky like a giant box. For the designer, the most important thing in here is functionalizing and aestheticize the geometrical form he used. Le Corbusier has also given weight to rate and ratio between forms in his urban designs and he used cubic forms from the very beginning of his designs, even in his sketches [4].

As a pioneer of avant-garde architecture, using technology in his architecture without a hesitation, where geometrical forms are prominent in the structures, Le Corbusier has used history and tradition in architecture and became an idol in architecture with his designs.

\section{THE IMPORTANCE OF MODEL IN DEVELOPMENT OF THE SPACE PERCEPTION}

$5 \mathrm{~m} \times 7 \mathrm{~m}$ melamine coated chipboard base plates that have been cut in CNC with a 1:50 scale was given to the students, for them to perceive the schematic plans and evaluate square meter by using the knowledge they have gained within the scope of the course. The reason why these base plates are prepared beforehand is that I spotted the mistakes the students made while drawing the wall thickness on the schematic plans when required within the extent of the course. Therefore, during the $\mathrm{CNC}$ cut, only outer walls and window openings were engraved on the base plates. 


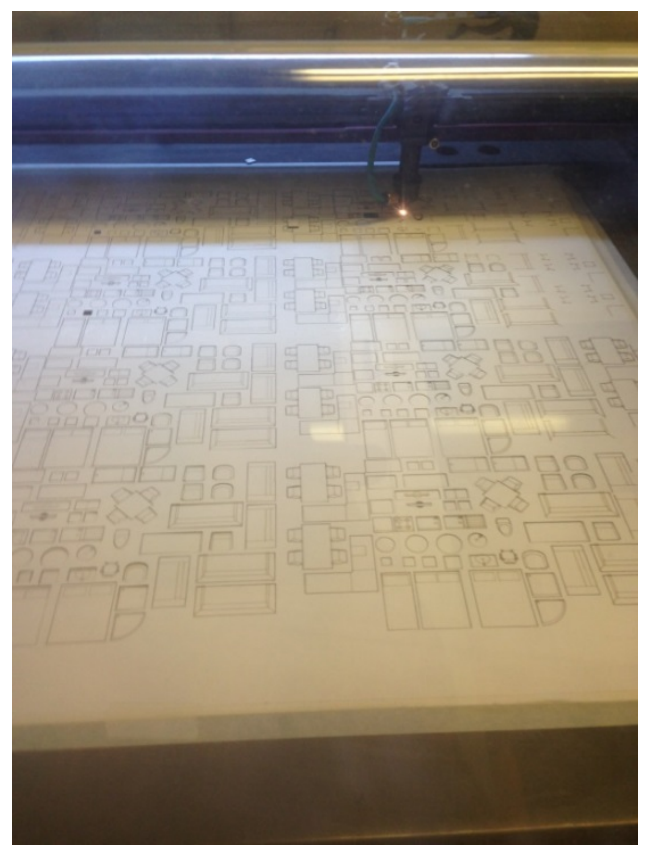

Image 2: CNC Cutting Machine (template cut)

This way, by showing them the exterior wall thickness, I aimed to help them perceive that the inner walls also should have thickness on the plan drawings.



Image 3-4-5 : Photos of Students During Practice 
I wanted the location, swinging direction and rate of the entrance door to be decided by students. I gave students $\mathrm{CNC}$ cut equipment elements in different sizes with 1:50 scale, to create a homeoffice solution on a $35 \mathrm{~m}^{2}$ area. Choices like how to organize these equipments while placing them, which size to pick were completely left to students. Also I purchased colored pens for the students who might want to separate the spaces with walls. Along with this jigsaw puzzle style practice, I also required students to prepare reports explaining their thoughts on why they organized the space as in the models they made. To help the students use their imagination without any constraints during the report writing process, I let them to make research on information about the materials and colors of the walls, tiles, furniture and other equipments, and to use $3 \mathrm{D}$ design software.

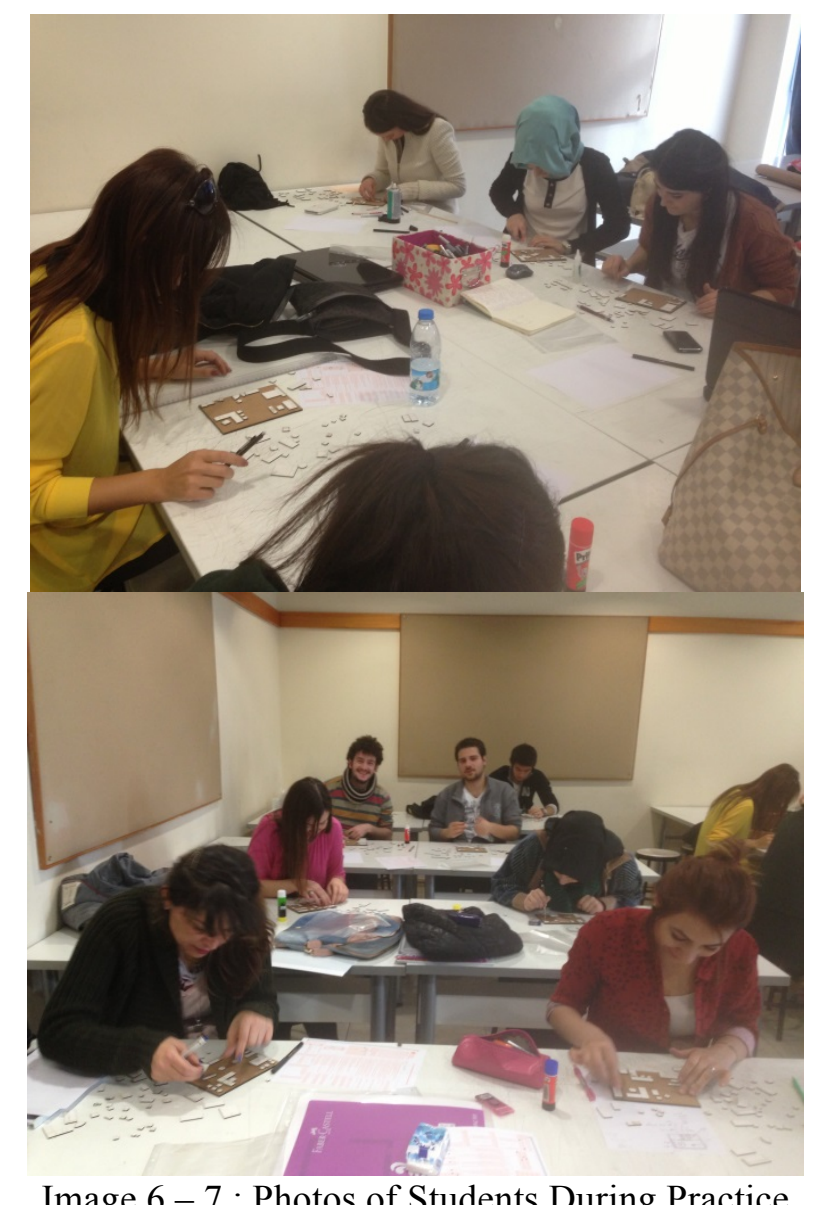

Most significant points of this 4 hours of period that draws my attention was seeing all the students enjoy the practice. While they mentioned that they have returned to their childhood with their own words, some of them have also drawn pictures with their own sketch pens and paints. I have made the same practice with a total of 120 students for 2 years and confirmed that students that have this same education created models with very different design aspects. 

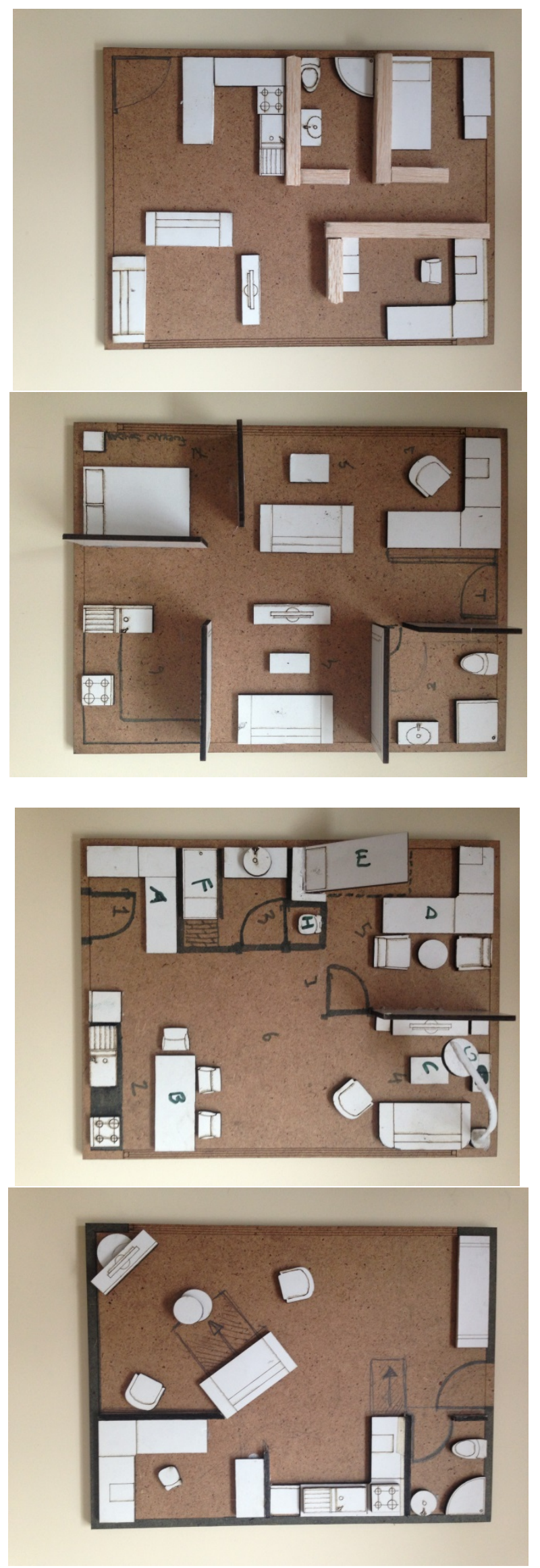


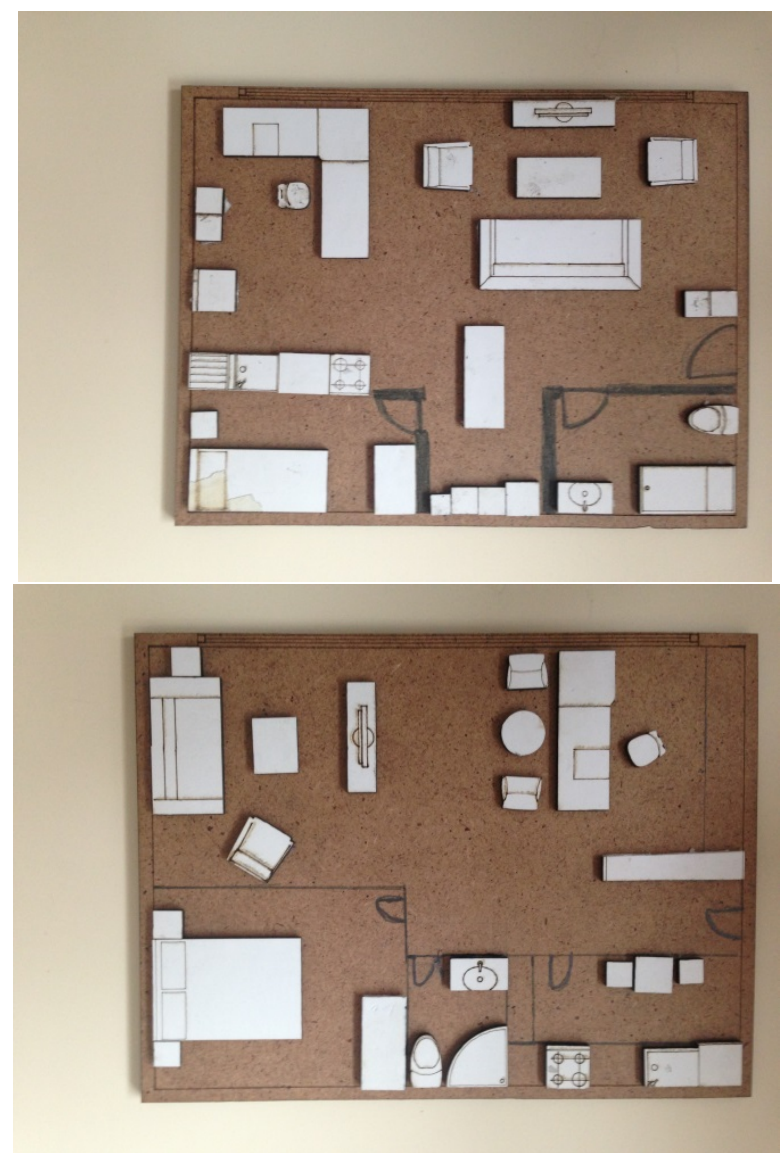

Image $8-9-10-11-12-13$ : Models Created by Students

\section{GEOMETRICAL FORMS AND SPACE ORGANIZATION}

The Interior architecture design is a process of organizing the space correctly, appropriately and as to meet the needs. Being the basis of the interior architecture, designing space is the practice of meeting the needs of the user and this practice forms an organization schematics. The result of this practice is an organization systematic, formed in several phases; from first phases as accumulation of architect's ideas to meet the needs of users and satisfy them, to further phases as receiving appreciation from the user. For interior architect, the most important thing is having the space meet the requested features. In this phase, interior architect tries to create the design with the help of geometrical forms. The forms, methods and means, the architect uses while creating general setup and connections, designate the way he/she will follow. When it comes to the transference of ideas from imagination to reality, geometrical forms that make space perceivable and livable come into prominence.

Geometry's effect on space organization is significant and would catch our eyes, even we just throw a glance at architectural plan, in which it forms architectural space concept. Space and architecture concepts have different definitions for architect and interior architect. Vitrivius refers vertical posture of human body as the first archetypal space. [5]. In a similar approach, Schulz defines the reflection of verticality - that Vitrivius refers - on horizontal plane as "existential space" [6]. Aristotle defines space as "association of things or i.e. from its widest sense to its narrowest sense, it's the success of the association of concepts that encapsulates one another" [7]. According to Le Corbusier; "Our eyes were created to see the forms in light; shadows and light bring out the forms; cubes, cones, cylinders and pyramids are fundamental geometrical forms that are revealed by light accordingly." 


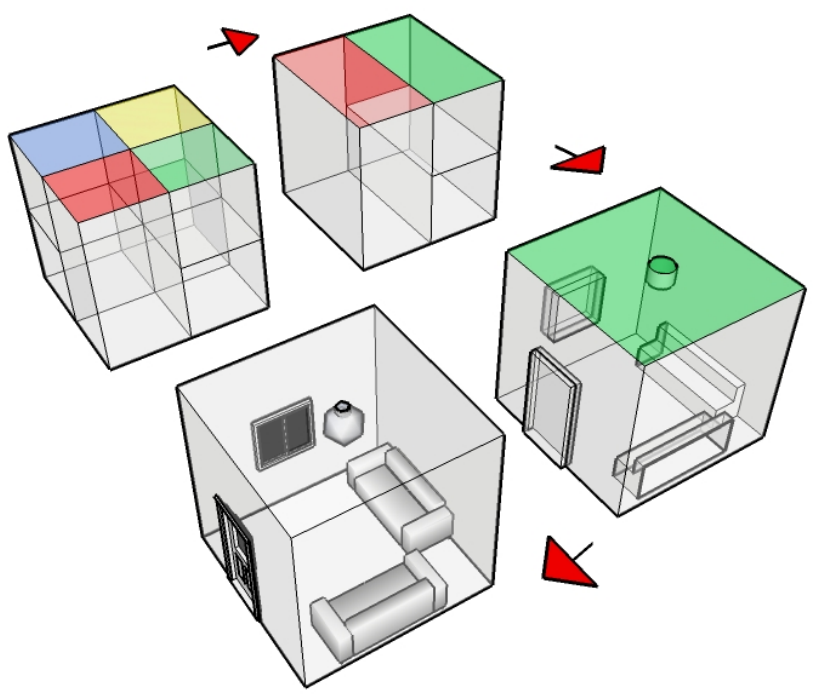

Figure 1: Example for design process from geometrical forms to formation of space (A. Eceoglu)

The most important element that gives space its characteristic is the surfaces that give two dimensional plan a volumetric characteristic by surrounding the borders of the geometrical form, which forms the expression of mass on plan [8]. We can refer to three significant functions in giving geometrical forms space characteristics:

- Surfaces give the forms their space characteristics, which they restrict or surround.

- Surfaces organize the relation between the forms and spaces they surround and other forms and spaces, in compliance with other forms surface characteristics.

- Surfaces define the level, order and form of relation between spaces, which they restrict and surround, and their environment.

Considering this deterministic effect of surfaces on space, it's inevitable for "spatial sharedsurface mergence" and "spatial integration" concepts to create different setups for spaces, for they involve different surface relations [9].

\section{CONCLUSION}

It's an undeniable fact that geometrical forms appear before us during various phases, from design to application. For the essence of all the natural and artificial objects are composed of geometrical forms, utilizing them for students, who get vocational education, to develop their space perception, design perception and apprehend these for their mental development, is very important. Also, other relevant disciplines should be utilized in all phases of design works for architectural project development within vocational education systems. Along the path based on Le Corbusier's first house model "Cell", the importance of the existence of geometrical forms stands before us as an undeniable fact. Over the course of vocational education, this matter should not be avoided and also to prevent individuals from experiencing any problem on their profession after this education process, the interior architecture departments should also put emphasis on this matter.

In this research I made, most salient common trait of the home office designs of the students, who has been educated with the same model during the same period and requested to form schematic plans using the data they have been provided, is that all of the students positioned the wet areas on exact same locations. Besides that, they all positioned the wet areas (bathroom and kitchen) in parallel formation. Also, by ascribing different functions on equipments, they saved space, and thus, they could use the window openings as to utilize light more efficiently. "Stack 
distribution schematic plan", which was generally used for organizing the space in the models, is as follows:

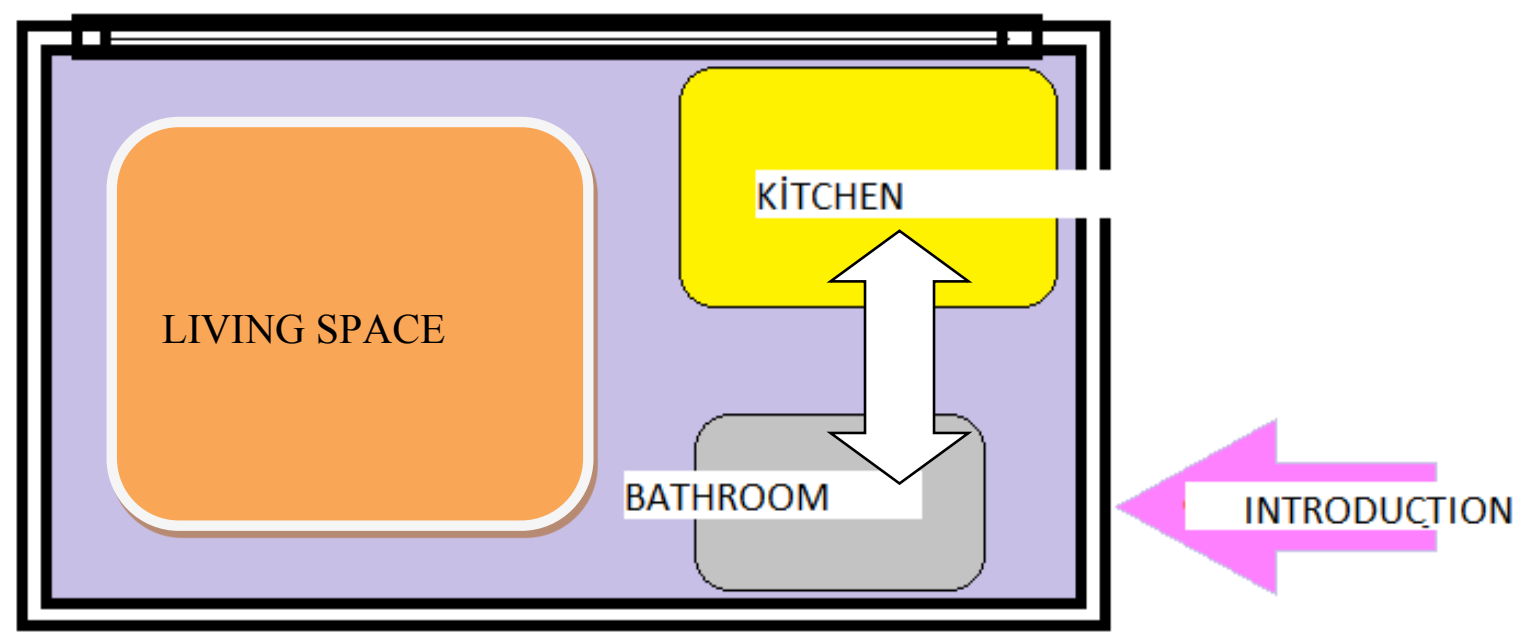

Figure 2: Organization schematics derived from the designs of students

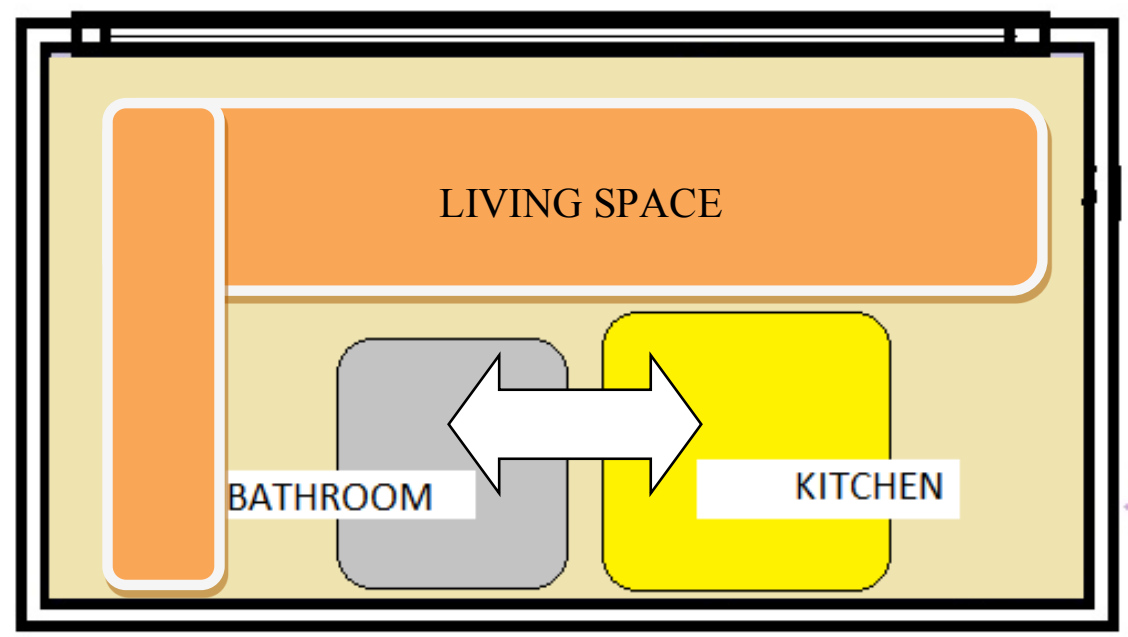

Figure 3: Organization schematics derived from the designs of students

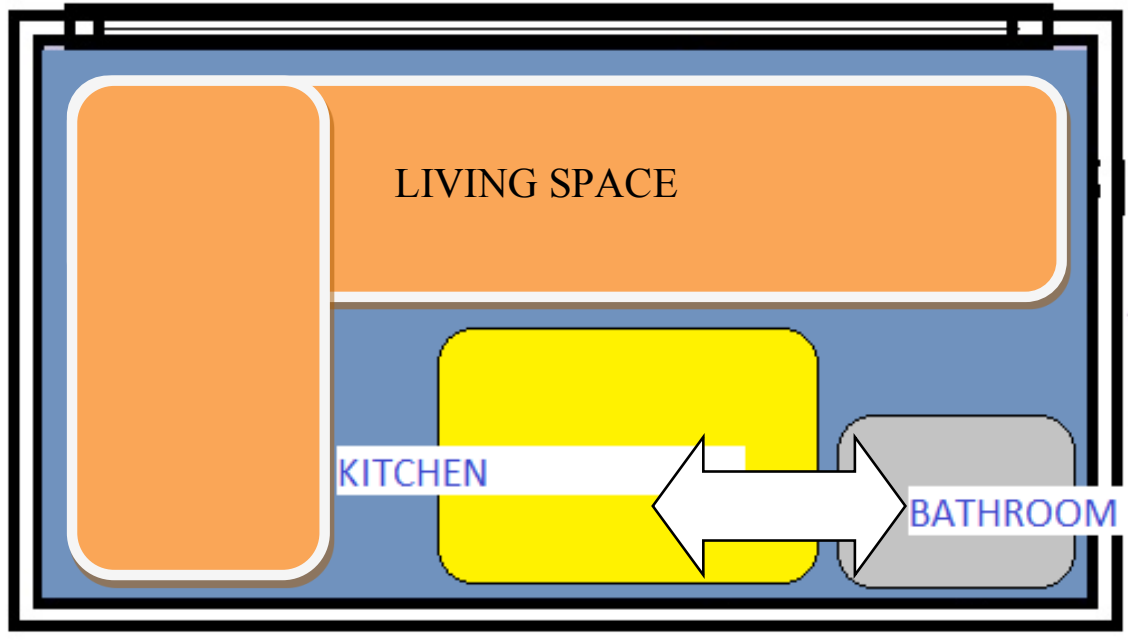


Figure 4 Organization schematics derived from the designs of students

\section{REFERENCES}

1. Svetozar Zavarichin and Vladimir Lisovskij. World Applied Sciences Journal 23 (Problems of Architecture and Construction): 149-152, 2013, ISSN 1818-4952

2. Victor Mikhaylovich Molchanov and Marianna Viktorovna Blagova, WASJ World Appl. Sci. J., 27 (9): 1194-1200, 2013

3. Frampton, K., 2011. Labour, work and architecture: Collected essays on architecture and design. London, New York, US: Phaidon Press, pp: 352.

4. Richards, S., 2003. Le Corbusier and the Concept of Self. New Haven \& London: Yale University Press.

5. Collective, Le Corbusier ve Kent (Le Corbusier and City), Boyut Yayin Grubu

6. Vitruvius, (1998), Mimarlik Uzerine On Kitap (The Ten Books on Architecture), (translated by: Guven, S.) YEM Yayinevi: Istanbul

7. Von Meiss, P. (1990), Elements of Architecture: from Form to Place, Van Nostrand Reinhold Pub.: New York.

8. Schulz, C. N. (1971), Existence Space and Architecture, Praeger Publishers Inc.: New York.

9. Dincer, O., Ege Mimarlık Dergisi (Aegean Architecture Magazine), 2005/2 - 54 